\title{
Protective measures taken up by the College for conducting examinations during COVID-19 pandemic: A Satisfaction survey from students and staff
} Aluri Sai Padma ${ }^{1}$, Nomula Chandan Babu ${ }^{2}$, Davuluri Rajani ${ }^{3}$, Gopinathan Sumathi Mini ${ }^{4}$, Isukapati Rachana Kumari ${ }^{5}$

${ }^{1}$ Assistant Professor, Department of Biochemistry, Bhavan's Vivekananda College, Sainikpuri, Secunderabad-94, Telangana, India; ${ }^{2}$ Assistant Professor, Department of Mathematics and Statistics, Bhavan's Vivekananda College, Sainikpuri, Secunderabad-94, Telangana, India; ${ }^{3}$ Assistant Professor, Department of Biochemistry, Bhavan's Vivekananda College, Sainikpuri, Secunderabad-94, Telangana, India; ${ }^{4}$ Assistant Professor, Department of Department of Mathematics and Statistics, Bhavan's Vivekananda College, Sainikpuri, Secunderabad-94, Telangana, India; ${ }^{5}$ Assistant Professor, Department of Genetics and Biotechnology, Bhavan's Vivekananda College, Sainikpuri, Secunderabad-94, Telangana, India.

\begin{tabular}{|l|l|l|l|l|l|l|l|}
\hline Abstract & Introduction & Methodology & Results & Conclusion & References & Citation & Tables/ Figures \\
\hline
\end{tabular}

\section{Corresponding Author}

Dr. A. Sai Padma, Department of Biochemistry, Bhavan's Vivekananda College of Science, Humanities and Commerce, Sainikpuri, Secunderabad

E Mail ID: saipadmabhavans@yahoo.co.in

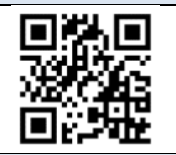

\section{Citation}

Padma AS, Babu NC, Rajani D, Mini GS, Kumari IR. Protective measures taken up by the College for conducting examinations during COVID-19 pandemic: A Satisfaction survey from students and staff. Indian J Comm Health. 2020;32(4):727-730. https://doi.org/10.47203/IJCH.2020.v32i04.020

Source of Funding: Nil Conflict of Interest: None declared

\section{Article Cycle}

Received: 10/11/2020; Revision: 21/11/2020; Accepted: 05/12/2020; Published: 31/12/2020

This work is licensed under a Creative Commons Attribution 4.0 International License.

\section{Abstract}

Background: Conducting examinations by the educational institutions during COVID-19 pandemic is highly challenging to contain spread of infection and instil confidence amongst students and staff. Objective: To test the satisfaction levels of students and staff towards the protective measures taken up by college during examinations in the COVID-19 pandemic. Design: Research study is target group oriented, online data collection through social media. Methods and Material: Online survey was conducted $(n=768)$ using a questionnaire with multiple-choice questions. Statistical analysis used: Chi-square test, ANOVA one way classification and t-test for difference of means through python. Results: Responses of the survey have indicated that sanitization measures taken were very effective $(97.0 \%)$, felt safe in the examination rooms $(97.0 \%)$, were instructed about physical distancing (98.83\%), satisfied for protective measures taken at entrance $(92.93 \%)$, college website was followed to understand sanitization measures taken up (90.49\%) Conclusion: By ensuring effective implementation of all protective measures, confidence among students and staff can be instilled and relieves stress and anxiety amongst them during COVID-19 pandemic.

\section{Keywords}

Protective Measures; Sanitization; Examination Halls; ANOVA; Chi Square Test.

\section{Introduction}

Environmental measures need to be taken in workplaces to reduce the risk of transmission of SARS-CoV-2 to individuals through contact with infected subjects, objects, equipment, or contaminated environmental surfaces. SARS-CoV-2 (COVID-19) can be highly stable in a favorable environment (1). Persistence of COVID-19 virus was found to be with different time periods on various surfaces (2). Like other corona viruses, SARS-CoV-2 is 
an enveloped virus with a fragile outer lipid envelope that makes it more susceptible to disinfectants compared to non-enveloped viruses (3). To contain spread of COVID-19 while conducting examinations by the educational institutions, the Government of India, Ministry of Health \& Family Welfare released a revised SOP on $10^{\text {th }}$ September, 2020 regarding all preventive measures to be followed during this COVID-19 pandemic time (4). The college under study has followed all the guidelines instructed. Apart from taking all other protective measures at entrance, campus and in examination halls, sanitization in examination halls and other common areas is done with $1 \%$ sodium hypochlorite on floor and $5 \%$ Dettol (Chloroxylenol as active ingredient) on metal benches, which were shown effective against SARS-CoV-2 in 5 minutes of treatment (2).Total 514 examination halls were sanitized during the conduct of these final semester end examinations for both undergraduate and postgraduate students during months of September and October, 2020 and nearly 1000 final year students have attended these exams.

\section{Aims \& Objectives}

The main aim of study is to test satisfaction of students and staff towards the protective measures taken including sanitization during the examinations in the COVID-19 pandemic period. To achieve this aim, work was planned through the following objectives:

1. Effectiveness of sanitization measures taken by college in the examination halls.

2. Feeling safe in the examination halls.

3. Physical distancing at the entrance and examination halls.

4. Protective measures at the entrance including checking for mask/ temperature and hand sanitization.

\section{Material \& Methods}

A satisfaction survey was conducted using a survey monkey questionnaire, which consisted of 10 questions (free version). The questionnaire contained multiple-choice questions with predefined answers offering respondents the possibility to choose and rank among several options or the possibility to grade on "Excellent" to "Very Poor" scale. The data was collected from faculty, non-teaching staff, undergraduate and postgraduate students. Overall 768 independent responses were received from the above said categories. Consent was taken from the respondents to use data for further research. Complete confidentiality was maintained throughout the collection and analysis of data.

Statistical analysis used: Chi-square test, ANOVA one way classification and t-test for difference of means through python were used for data analysis.

\section{Results}

The data collected from all participants was analyzed for various parameters tested and the complete data is presented in the form of number of responses and percentage (Table 1). Total $97.0 \%$ respondents felt that sanitization measures taken up by college were effective and majority of them (97.0\%) felt safe in the examination rooms. Nearly $99 \%$ responded as they were instructed about physical distancing, and also they were satisfied with the protective measures taken at the entrance (92.93\%). Large percentage (90.49\%) followed college website to understand sanitization measures taken up. Statistical analysis based on genders and professions (Table 2 ) revealed that there is a significant difference between professions on various parameters of protective measures taken up. Teaching and non-teaching faculty members have shown more satisfaction compared to the student community and the reason could be due to lack of keen observation of all parameters implemented by students, compared to staff members. Female participants are more satisfied with the effectiveness of sanitization measures taken up compared to male participants, implies their thorough observation. Irrespective of gender and professions, all the participants have responded as they were instructed about physical distancing at entrance and in examination halls and this is one of the important protective measures to limit the spread of infection among the staff and students. Visiting college website by $90.49 \%$ shows their attentiveness to understand the safety measures taken, to attend examinations comfortably and this channel of information flow would definitely build trust and confidence amongst them.

\section{Discussion}

This is the first study from India assessing the implementation status of protective measures for conducting examinations during COVID-19. A Joint Task Force of eminent public health experts of India was constituted by Indian Public Health Association (IPHA) and Indian Association of Preventive and Social Medicine (IPHA) to help the Government of 
India for containment of COVID-19 pandemic in the country. The action plan for control of pandemic included source containment through increase of public awareness and practice of preventive measures by ensuring physical distancing with social bonding, avoid social stigma and ensure universal mask usage $(5,6)$. So, it is necessary for every individual and organizations to follow the guidelines laid by the government and contain the spread of COVID-19 infection. The other guidelines which were suggested at workplace in general can be taken into consideration (7).

\section{Conclusion}

Satisfactory survey from students and staff has shown high satisfaction towards all protective measures taken up by the college during examinations.

\section{Recommendation}

All educational institutions should follow strict sanitization and other protective measures for conduct of examinations during COVID-19 pandemic time and instil safety and confidence amongst staff and students.

\section{Limitation of the study}

The study was conducted amongst first phase of examinations for final year students and further studies during the other phases of examinations gives more generalized opinion on safety levels during the pandemic time.

\section{Relevance of the study}

To contain spread of COVID-19 infection, Ministry of Health and Family Welfare, Government of India has issued guidelines to all educational institutions which may not be adhered to strictly. This study looked into important parameters related to individual safety and containment of infection while conducting the examinations by the educational institute.

\section{Authors Contribution}

All authors have contributed equally.

\section{Tables}

TABLE 1 NUMBER AND PERCENTAGE INDICATION OF RESPONSES TO VARIOUS QUESTIONS IN THE QUESTIONNAIRE, PERTAINING TO SANITIZATION AND OTHER PROTECTIVE MEASURES TAKEN BY THE COLLEGE

\begin{tabular}{|l|l|l|l|l|}
\hline S. No. & Sanitization measures & Answer choice & No. of responses & $\%$ of responses \\
\hline $\mathbf{1}$ & $\begin{array}{l}\text { How effective did you find the sanitization measures } \\
\text { taken by the college in the examination halls? }\end{array}$ & Excellent & 293 & $38.15 \%$ \\
\cline { 3 - 5 } & & Very good & 285 & $37.11 \%$ \\
\hline & & Good & 171 & $22.27 \%$ \\
\cline { 2 - 4 } & & Poor & 14 & $1.82 \%$ \\
\hline
\end{tabular}

\section{Acknowledgement}

Authors are grateful to the Management and Principal, Prof.Y.Ashok, Bhavan's Vivekananda College to permit us to acquire the data required from students and staff of the college. Authors duly acknowledge Dr.Suresh and Dr. Kondal Reddy for extending their cooperation during sanitization process in the college.

\section{References}

1. van Doremalen N, Bushmaker T, Morris DH, Holbrook MG Gamble A, Williamson BN, Tamin A, Harcourt JL, Thornburg NJ, Gerber SI, Lloyd-Smith JO, de Wit E, Munster VJ. Aerosol and Surface Stability of SARS-CoV-2 as Compared with SARS- CoV-1. N Engl J Med. 2020;16;382(16):1564-1567. doi: 10.1056/NEJMc2004973. Epub 2020 Mar 17. PMID: 32182409; PMCID: PMC7121658.[PubMed].

2. Chin AWH, Chu JTS, Perera MRA, Hui KPY, Yen HL, Chan MCW, Peiris M, Poon LLM. Stability of SARS-CoV-2 in different environmental conditions. Lancet Microbe. 2020;1(1):e10. doi: 10.1016/S2666-5247(20)30003-3. Epub 2020 Apr 2. PMID: 32835322; PMCID: PMC7214863.[PubMed]

3. Rutala WA, Weber DJ. Best practices for disinfection of noncritical environmental surfaces and equipment in health care facilities: A bundle approach. Am J Infect Control. 2019;47S:A96-A105. doi: 10.1016/j.ajic.2019.01.014. PMID: 31146858. [PubMed].

4. Revised SOP on preventive measures to be followed while conducting examinations to contain spread of COVID-19, https://www.mohfw.gov.in/pdf/RevisedSOPonpreventive measures to be followed while conducting examinations to contain spread of COVID19.pdf

5. Rai SK, Zodpey S, Ghosh S, Kadri A. Joint statement on COVID-19 pandemic in India: Review of current strategy and the way forward." Indian journal of Community Health. 2020;32(2):170-174. https://doi.org/10.47203/IJCH.2020. v32i02SUPP.001

6. Second-Joint-Statement-of-IPHA-IAPSM-and-IAE-onCOVID-19-containment-plan-May-25-2020_Shorterversion-final. $\quad$ https://www.iphaonline.org/wpcontent/uploads/2020/05/Second-Joint-Statement-ofIPHA-IAPSM-and-IAE-on-COVID-19-containment-plan-May25-2020 Shorter-version-final.pdf

7. Cirrincione Luigi, et al., COVID-19 pandemic: Prevention and protection measures to be adopted at the workplace. Sustainability; https://www.mdpi.com/2071-1050/12/9/3603\# 


\begin{tabular}{|c|c|c|c|c|}
\hline & & Very poor & 5 & $0.65 \%$ \\
\hline \multirow[t]{5}{*}{2} & \multirow[t]{5}{*}{ How safe did you feel in examination hall? } & Extremely safe & 247 & $32.16 \%$ \\
\hline & & Very safe & 359 & $46.74 \%$ \\
\hline & & Somewhat safe & 139 & $18.10 \%$ \\
\hline & & Not so safe & 17 & $2.21 \%$ \\
\hline & & Not at all safe & 6 & $0.78 \%$ \\
\hline \multirow[t]{2}{*}{3} & \multirow{2}{*}{$\begin{array}{l}\text { Were you instructed to follow the required physical } \\
\text { distancing from the entrance and in the examination } \\
\text { hall? }\end{array}$} & Yes & 759 & $98.83 \%$ \\
\hline & & No & 9 & $1.17 \%$ \\
\hline \multirow[t]{5}{*}{4} & \multirow{5}{*}{$\begin{array}{l}\text { How were the protective measures taken at the } \\
\text { entrance including mask/temperature/hand } \\
\text { sanitization? }\end{array}$} & Very satisfied & 347 & $45.16 \%$ \\
\hline & & Satisfied & 367 & $47.77 \%$ \\
\hline & & $\begin{array}{l}\text { Neither satisfied } \\
\text { nor dissatisfied }\end{array}$ & 40 & $5.24 \%$ \\
\hline & & Dissatisfied & 8 & $1.05 \%$ \\
\hline & & Very dissatisfied & 6 & $0.79 \%$ \\
\hline \multirow[t]{2}{*}{5} & \multirow{2}{*}{$\begin{array}{l}\text { Did you follow the college website to understand the } \\
\text { sanitization measures taken up by the college? }\end{array}$} & Yes & 695 & $90.49 \%$ \\
\hline & & No & 73 & $9.51 \%$ \\
\hline
\end{tabular}

\section{TABLE 2 ASSOCIATION BETWEEN GENDER, PROFESSION AND VARIOUS PROTECTIVE MEASURES}

\section{TAKEN UP BY COLLEGE}

\begin{tabular}{|c|c|c|c|c|}
\hline $\begin{array}{l}\text { S. } \\
\text { No. }\end{array}$ & Testing parameter & Statistical method used & p-Value & Inference \\
\hline 1 & $\begin{array}{l}\text { Difference of opinion between genders on } \\
\text { effectiveness of sanitization measures taken up } \\
\text { by college. }\end{array}$ & $\begin{array}{l}\text { chi-square test for } \\
\text { independents of } \\
\text { attributes. }\end{array}$ & 0.0115 & $\begin{array}{l}\text { There is an } \\
\text { association }\end{array}$ \\
\hline 2 & $\begin{array}{l}\text { Difference of opinion between professions on } \\
\text { effectiveness of sanitization measures taken up. }\end{array}$ & $\begin{array}{l}\text { ANOVA one- way } \\
\text { classification }\end{array}$ & 0.0186 & $\begin{array}{l}\text { There is a significant } \\
\text { difference. }\end{array}$ \\
\hline 3 & $\begin{array}{l}\text { Difference of opinion between genders in } \\
\text { feeling safe in the examination halls. }\end{array}$ & $\begin{array}{l}t \text { - test for difference of } \\
\text { means }\end{array}$ & 0.5045 & $\begin{array}{l}\text { No significant } \\
\text { difference. }\end{array}$ \\
\hline 4 & $\begin{array}{l}\text { Difference of opinion between professions in } \\
\text { feeling safe in the examination halls. }\end{array}$ & $\begin{array}{l}\text { ANOVA } \\
\text { classification. }\end{array}$ & 0.0302 & $\begin{array}{l}\text { There is a significant } \\
\text { difference. }\end{array}$ \\
\hline 5 & $\begin{array}{l}\text { Difference of opinion between genders in feeling } \\
\text { satisfied for protective measures taken at the } \\
\text { entrance. }\end{array}$ & $\begin{array}{l}\mathrm{t} \text { - test for difference of } \\
\text { means }\end{array}$ & 0.5883 & $\begin{array}{l}\text { No significant } \\
\text { difference. }\end{array}$ \\
\hline 6 & $\begin{array}{l}\text { Difference of opinion between professions in } \\
\text { feeling satisfied for protective measures taken at } \\
\text { the entrance. }\end{array}$ & $\begin{array}{l}\text { ANOVA } \\
\text { classification. }\end{array}$ & 0.0186 & $\begin{array}{l}\text { There is a significant } \\
\text { difference }\end{array}$ \\
\hline
\end{tabular}

